\title{
CATTLE MANURE FERTILIZATION INCREASES FIG YIELD
}

\author{
Sarita Leonel ${ }^{1 *}$; Marco Antonio Tecchio ${ }^{2}$ \\ ${ }^{1}$ UNESP/FCA - Depto. de Produção Vegetal, C.P. 237 - 18610-307 - Botucatu, SP - Brasil. \\ ${ }^{2}$ IAC - Centro Avançado de Pesquisa Tecnologia do Agronegócio de Frutas, C.P. 11 - 13214-820 - Jundiaí, SP - \\ Brasil. \\ *Corresponding author <sarinel@fca.unesp.br>
}

\begin{abstract}
Fertilization using organic compounds is complementary to chemical fertilization, being essential to integrated fruit production. Reports on fig tree (Ficus carica L.) organic fertilization and mineral nutrition are worldwide scarce, especially in Brazil. This experiment aimed to evaluate the effects of cattle manure fertilization on the yield and productivity of the fig tree 'Roxo de Valinhos' in Botucatu, São Paulo State, Brazil, during the 2002/03, 2003/04, 2004/05 and 2005/06 crop cycles. Plants aged one, two, three and four year olds received the following cattle manure treatments: control (no fertilizer), $25 \%, 50 \%, 75 \%, 100 \%, 125 \%$ and $150 \%$ of the recommended $\mathrm{N}$ level for this crop. The evaluated variables were: fruit number, weight and mean diameter, plant yield and productivity. The application of cattle manure increased productivity, yield and fruit number, slightly affecting fruit dimensions. After four years of cattle manure application, the best results were obtained with 76 to $124 \%$ of the $\mathrm{N}$ level recommended for the fig crop.
\end{abstract}

Key words: Ficus carica L., nitrogen, organic matter

\section{ADUBAÇÃO COM ESTERCO DE CURRAL NA PRODUÇÃO DA FIGUEIRA}

\begin{abstract}
RESUMO: A adubação com compostos orgânicos é complementar à adubação química e especialmente necessária para a produção integrada de frutas. Trabalhos de pesquisa com adubação orgânica e nutrição mineral da figueira (Ficus carica L.) são escassos em todo o mundo e particularmente, no Brasil. O experimento teve como objetivo avaliar os efeitos da adubação orgânica com esterco de curral na produção e produtividade da figueira 'Roxo de Valinhos' em Botucatu-SP, nos ciclos de produção de 2002/03, 2003/04, 2004/05 e 2005/06. As plantas com idade de um, dois, três e quatro anos receberam os tratamentos com doses de esterco de curral correspondentes a: testemunha (sem adubação), 25\%, 50\%, 75\%, 100\%, 125\% e 150\% da dose recomendada de $\mathrm{N}$ para a cultura. As variáveis avaliadas foram número, peso e diâmetro médio dos frutos, produção por planta e produtividade. A aplicação de esterco de curral aumentou a produtividade, produção e número de frutos, havendo poucas alterações nas dimensões dos mesmos. Após os quatro anos de aplicação do esterco de curral, obtiveram-se melhores resultados com 76 a $124 \%$ de da dose de $\mathrm{N}$ recomendada para a cultura da figueira.
\end{abstract}

Palavras-chave: Ficus carica L., nitrogênio, matéria orgânica

\section{INTRODUCTION}

Fig trees (Ficus carica L.) are cultivated in approximately 40 countries, predominantly in the Mediterranean region. Turkey is the major fig producing country, accounting for $26 \%$ of the total fig world's production. Following Turkey is Brazil, the world's second major exporter of figs, with the advantage of producing during the Mediterranean off-season (Maiorano, 2006).

The fig tree has deciduous leaves and is native to the Mediterranean region, where either temperate or subtropical climate predominates. Thus, it is adapted to several climates and can be cultivated in both sub- tropical and temperate regions (Penteado \& Franco, 1997).

This plant thrives well in several soils (Rigitano, 1964; Gomes, 1987; Penteado \& Franco, 1997; Corrêa $\&$ Boliani, 2000) provided it is deep, well drained and rich in organic matter. Producers' experience has revealed that the higher the levels of organic fertilizer, the better the results are both for yield and fruit quality. Another reason for the interest in organic fertilization is the growth of the certified organic market, since they get higher prices. However, scientific research into the fig tree requirements in organic fertilization is scarce and not conclusive. 
Fernandes \& Buzetti (1999) considered organic fertilization and/or mulch priority studies almost a decade ago. In this paper, we report the results of organic fertilization on the yield of fig trees (Ficus carica, L.) cultivar 'Roxo de Valinhos' during four crop cycles.

\section{MATERIAL AND METHODS}

The experiment was carried out in Botucatu, São Paulo State, Brazil (22 $52^{\circ} \mathrm{S}, 48^{\circ} 25^{\prime} \mathrm{W}, 810 \mathrm{~m}$ altitude). The local climate is classified as Cwa after Koppen (Curi, 1972), with rainy summers and dry winters, and the highest average temperature is above $22^{\circ} \mathrm{C}$ (Cunha et al., 1999). The soil is Rhodic Hapludalf, according to the criteria established by United States Soil Conservation Service (1988). The initial chemical characteristics of the $20 \mathrm{~cm}$ topsoil, determined based on the methodology of Raij and Quaggio (1983), were: $\mathrm{pH}\left(\mathrm{CaCl}_{2}\right)=$ 4.2; O.M. $=24 \mathrm{~g} \mathrm{dm}^{-3} ; \mathrm{P}($ resin $)=3 \mathrm{mg} \mathrm{dm}^{-3} ; \mathrm{H}+\mathrm{Al}$ $=84 \mathrm{mmol}_{\mathrm{c}} \mathrm{dm}^{-3} ; \mathrm{K}=1.4 \mathrm{mmol}_{\mathrm{c}} \mathrm{dm}^{-3} ; \mathrm{Ca}=12 \mathrm{mmol}_{\mathrm{c}}$ $\mathrm{dm}^{-3} ; \mathrm{Mg} \stackrel{\mathrm{c}}{=} 5 \mathrm{mmol}_{\mathrm{c}} \mathrm{dm}^{-3} ;$ Sum of bases $=18 \mathrm{mmol}_{\mathrm{c}}^{\mathrm{c}}$ $\mathrm{dm}^{-3} ; \mathrm{CEC}=102 \mathrm{mmol}_{\mathrm{c}} \mathrm{dm}^{-3}$; Base Saturation $=18 \%$.
The experimental area was plowed and dolomitic limestone was applied to increase base saturation up to $70 \%$ (Raij et al., 1997). Fig nursery trees 'Roxo de Valinhos' were planted in September 2001, spaced 3 $\mathrm{m}$ between lines and $2 \mathrm{~m}$ between plants, constituting a plot of 1660 plants $\mathrm{ha}^{-1}$. Planting holes $(60 \mathrm{~cm} \times$ $60 \mathrm{~cm} \times 60 \mathrm{~cm})$ received 20 litters cattle manure, $1 \mathrm{~kg}$ lime, and $1 \mathrm{~kg}$ magnesium pyrophosphate containing boron and zinc. Plants were pruned every July between 2002 and 2005 to obtain 9-productive-branch arrangement, which is considered appropriate for plants in the formation stage.

Treatments consisted of cattle manure levels according to the recommended $\mathrm{N}$ level for the fig tree: control (no fertilizer), $25 \%, 50 \%, 75 \%, 100 \%, 125 \%$ and $150 \%$ of the recommended $\mathrm{N}$ level (Table 1). Since these levels depend on the tree size and as the $\mathrm{N}$ content in cattle manure varied (Table 2), the actual quantity of applied manure varied every year (Table 1). Half of the manure level was applied in August and the remaining in September from 2002 to 2005.

Table 1 - Nitrogen levels used in fig tree fertilizations during four crop cycles (August/2002 to August/2005). Botucatu, São Paulo State, Brazil. 2007.

\begin{tabular}{|c|c|c|c|c|c|c|c|c|}
\hline \multirow[t]{2}{*}{$\% \mathrm{~N}$} & \multicolumn{4}{|c|}{$\mathrm{N}$ levels } & \multicolumn{4}{|c|}{ Manure levels } \\
\hline & $1^{\text {st }}$ year & $2^{\text {nd }}$ year & $3^{\text {rd }}$ year & $4^{\text {th }}$ year & $1^{\text {st }}$ year & $2^{\text {nd }}$ year & $3^{\text {rd }}$ year & $4^{\text {th }}$ year \\
\hline$\%$ & -..... & g p & lant -..-- & - & 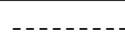 & .... kg & lant -..- & - \\
\hline 0 & 0 & 0 & 0 & 0 & 0 & 0 & 0 & 0 \\
\hline 25 & 10 & 20 & 30 & 30 & 0.8 & 0.82 & 1.9 & 3.6 \\
\hline 50 & 20 & 40 & 60 & 60 & 1.6 & 1.64 & 3.8 & 7.3 \\
\hline 75 & 30 & 60 & 90 & 90 & 2.4 & 2.46 & 5.7 & 11.0 \\
\hline 100 & 40 & 80 & 120 & 120 & 3.2 & 3.28 & 7.6 & 14.3 \\
\hline 125 & 50 & 100 & 150 & 150 & 4.0 & 4.10 & 9.5 & 18.0 \\
\hline 150 & 60 & 120 & 180 & 180 & 4.8 & 4.92 & 11.4 & 22.0 \\
\hline
\end{tabular}

Table 2 - Chemical analysis of cattle manure used in fig tree fertilizations (Samples - 1: August/2002; 2: June/2003; 3: July/ 2004; 4: July/2005.). Botucatu, São Paulo State, Brazil, 2007.

\begin{tabular}{|c|c|c|c|c|c|c|c|c|c|}
\hline Sample & $\mathrm{N}$ & $\mathrm{P}_{2} \mathrm{O}_{5}$ & $\mathrm{~K}_{2} \mathrm{O}$ & humidity & Organic matter & $\mathrm{C}$ & $\mathrm{Ca}$ & $\mathrm{Mg}$ & $S$ \\
\hline \multicolumn{10}{|c|}{ - } \\
\hline 1 & 1.26 & 1.52 & 1.68 & 41.0 & 43.00 & 23.89 & 1.50 & 0.50 & 0.18 \\
\hline 2 & 2.45 & 2.14 & 1.55 & 37.0 & 41.00 & 23.00 & 1.14 & 0.45 & 0.35 \\
\hline 3 & 1.58 & 0.94 & 0.92 & 42.3 & 39.00 & 21.70 & 1.29 & 0.84 & 0.21 \\
\hline 4 & 1.12 & $1.2 \mathrm{O}$ & 0.80 & 30.2 & 34.00 & 18.90 & 0.84 & 0.36 & 0.34 \\
\hline Sample & $\mathrm{Fe}$ & $\mathrm{Cu}$ & $\mathrm{Mn}$ & $\mathrm{Na}$ & $\mathrm{Zn}$ & $\mathrm{pH}^{*}$ & $\mathrm{C} / \mathrm{N}$ & & \\
\hline \multicolumn{10}{|c|}{ - $\mathrm{mg}^{-1}$ dry matter $-\ldots$} \\
\hline 1 & 11,300 & 120 & 146 & $\mathrm{~N} / \mathrm{D}$ & 190 & 7.6 & 19 & & \\
\hline 2 & 7,950 & 302 & 308 & 1,860 & 300 & 7.2 & 9 & & \\
\hline 3 & 14,300 & 6 & 5,250 & 580 & 286 & 14.0 & 14 & & \\
\hline 4 & 24,950 & 156 & 278 & 1460 & 208 & 7.9 & 17 & & \\
\hline
\end{tabular}

*(in $\left.\mathrm{H}_{2} \mathrm{O}\right)$. Laboratory analyses of chemical fertilizers. DRN-FCA. 
An experimental design using randomized blocks with five replicates was used; plots for yield evaluation consisted of five plants each, and plots for leaf and soil analysis included ten plants each. Plants were individually evaluated on each crop cycle. The data obtained for each crop cycle was initially employed in the normality test using MINITAB software for all evaluated variables to verify whether there was normal distribution. Then, data were subjected to analysis of variance (F-test), followed by polynomial regression analysis when there was significance. For significant data, regression equations were fit to evaluate the behavior of the studied variables with the increase in the cattle manure level.

In addition to organic fertilization, all plants received pyrophosphate: $60 \mathrm{~g} \mathrm{P}_{2} \mathrm{O}_{5}$ in the $1^{\text {st }}$ and $2^{\text {nd }}$ crop cycles and $100 \mathrm{~g} \mathrm{P}_{2} \mathrm{O}_{5}$ in the $3^{5^{\text {td }}}$ and $4^{\text {th }}$ crop cycles. In December 2005, leaf and soil samples were collected from each experimental plot. Leaf sampling was done during complete flowering and in the beginning of fruit production; newly mature leaves were collected from the medial portion of branches from different sides of the plant which had appropriate sun exposure. Each sampling included fourteen leaves per plot, i.e. four leaves per plant. The levels of the nutrients N, P, K, $\mathrm{Ca}, \mathrm{Mg}, \mathrm{S}, \mathrm{B}, \mathrm{Cu}, \mathrm{Fe}, \mathrm{Mn}$ and $\mathrm{Zn}$ were determined according to the methodology proposed by Malavolta et al. (1987). Soil samples were taken at the $0-20 \mathrm{~cm}$ depth of the canopy projection fertilized area; a sub sample was also collected at every two plants (totaling twenty per plot) to make up a composite sample. The levels of $\mathrm{P}, \mathrm{K}, \mathrm{Ca}$ and $\mathrm{Mg}$, as well as $\mathrm{pH}$ and $\mathrm{V} \%$, were assessed according to the methodology described by Raij \& Quaggio (1983).

Commercially mature fruits were annually harvested from December to April in all crop cycles. The evaluated parameters were: number, weight $(\mathrm{g})$ and diameter $(\mathrm{mm})$ of fruits, yield per plant, and productivity per hectare $\left(\mathrm{t} \mathrm{ha}^{-1}\right)$.

\section{RESULTS AND DISCUSSION}

Soil samples $(0-20 \mathrm{~cm}$ depth) tested after all four crop cycles when compared with the initial ones, , indicated that cattle manure treatments did not affect macro and micronutrient levels (Table 3); they were considered appropriate for the fig tree (Raij \& Quaggio, 1983). Leaf analysis also indicated few alterations, corroborating the soil testing results (Table 4). However, cattle manure treatments influenced yield, productivity and fruit number in all crop cycles (Figure 1 and Table 5). Such variables fitted the quadratic

Table 3 - Macro and micronutrients, $\mathrm{pH}$, organic matter, sum of bases, effective CEC, and base saturation (\%) of the soil where fig trees were cultivated (Botucatu, São Paulo State, Brazil - December/2005).

\begin{tabular}{|c|c|c|c|c|c|c|c|c|c|}
\hline Values & $\begin{array}{c}\mathrm{pH} \\
\mathrm{CaCl}_{2}\end{array}$ & Organic matter & $P$ & $\mathrm{~K}$ & $\mathrm{Ca}$ & $\mathrm{Mg}$ & Sum bases & Effective CEC & Base saturation \\
\hline & & $\mathrm{g} \mathrm{dm}^{-3}$ & $\mathrm{mg} \mathrm{dm} \mathrm{dm}^{-3}$ & - & 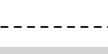 & ---- mmo & $\mathrm{l}_{\mathrm{c}} \mathrm{dm}^{-3} \ldots$ & & $\%$ \\
\hline Mean & 5.5 & 25 & 34 & 4.5 & 43 & 20 & 67 & 96 & 66 \\
\hline $\mathrm{CV}(\%)$ & 7.22 & 17.07 & 55.55 & 21.47 & 31.27 & 29.18 & 29.17 & 15.00 & 18.11 \\
\hline \multirow[t]{2}{*}{ Values } & B & $\mathrm{Cu}$ & $\mathrm{Fe}$ & $\mathrm{Mn}$ & $\mathrm{Zn}$ & & & & \\
\hline & $\ldots \ldots$ & - & $n g \mathrm{dm}^{-3}--$ & . & - & & & & \\
\hline Mean & 0.39 & 6.2 & 25 & 7.7 & 4.2 & & & & \\
\hline${ }^{1} \mathrm{CV}(\%)$ & 36.67 & 11.96 & 15.45 & 26.72 & 41.19 & & & & \\
\hline
\end{tabular}

${ }^{1} \mathrm{CV}=$ coefficient of variation

Table 4 - Macro and micronutrients of leaves from cattle manure-fertilized fig trees (Botucatu, São Paulo State, Brazil December/2005).

\begin{tabular}{|c|c|c|c|c|c|c|}
\hline Values & $\mathrm{N}$ & $\mathrm{P}$ & K & $\mathrm{Ca}$ & $\mathrm{Mg}$ & $\mathrm{S}$ \\
\hline \multicolumn{7}{|c|}{ - } \\
\hline Mean & 33 & 2.8 & 23 & 13 & 4.0 & 2.1 \\
\hline $\mathrm{CV}(\%)$ & 6.38 & 6.83 & 5.52 & 15.18 & 6.77 & 11.50 \\
\hline Values & B & $\mathrm{Cu}$ & $\mathrm{Fe}$ & $\mathrm{Mn}$ & $\mathrm{Zn}$ & \\
\hline \multicolumn{7}{|c|}{ - } \\
\hline Mean & 35 & 9 & 84 & 74 & 68 & \\
\hline${ }^{1} \mathrm{CV}(\%)$ & 18.54 & 23.50 & 11.17 & 29.17 & 13.56 & \\
\hline
\end{tabular}

${ }^{1} \mathrm{CV}=$ coefficient of variation 
Table 5 - Yield and productivity of fig trees during four crop cycles. Botucatu, São Paulo State, Brazil.

\begin{tabular}{lcccc}
\hline \multirow{2}{*}{ Nitrogen levels } & \multicolumn{4}{c}{ Crop cycles } \\
\cline { 2 - 4 }$\%$ & $2002 / 2003$ & $2003 / 2004$ & $2004 / 2005$ & $2005 / 2006$ \\
\hline 0 & 1.8 & 2.5 & 3.8 & 3.6 \\
25 & 2.2 & 2.7 & 3.8 & 5.3 \\
50 & 2.4 & 2.5 & 4.5 & 4.9 \\
75 & 4.6 & 2.4 & 5.1 & 7.9 \\
100 & 5.8 & 3.2 & 5.7 & 7.3 \\
125 & 3.6 & 2.8 & 5.3 & 6.7 \\
150 & 2.2 & 2.7 & 5.4 & 3.53 \\
\hline CV $(\%)$ & 27.64 & 10.76 & 10.39 & \\
\hline
\end{tabular}
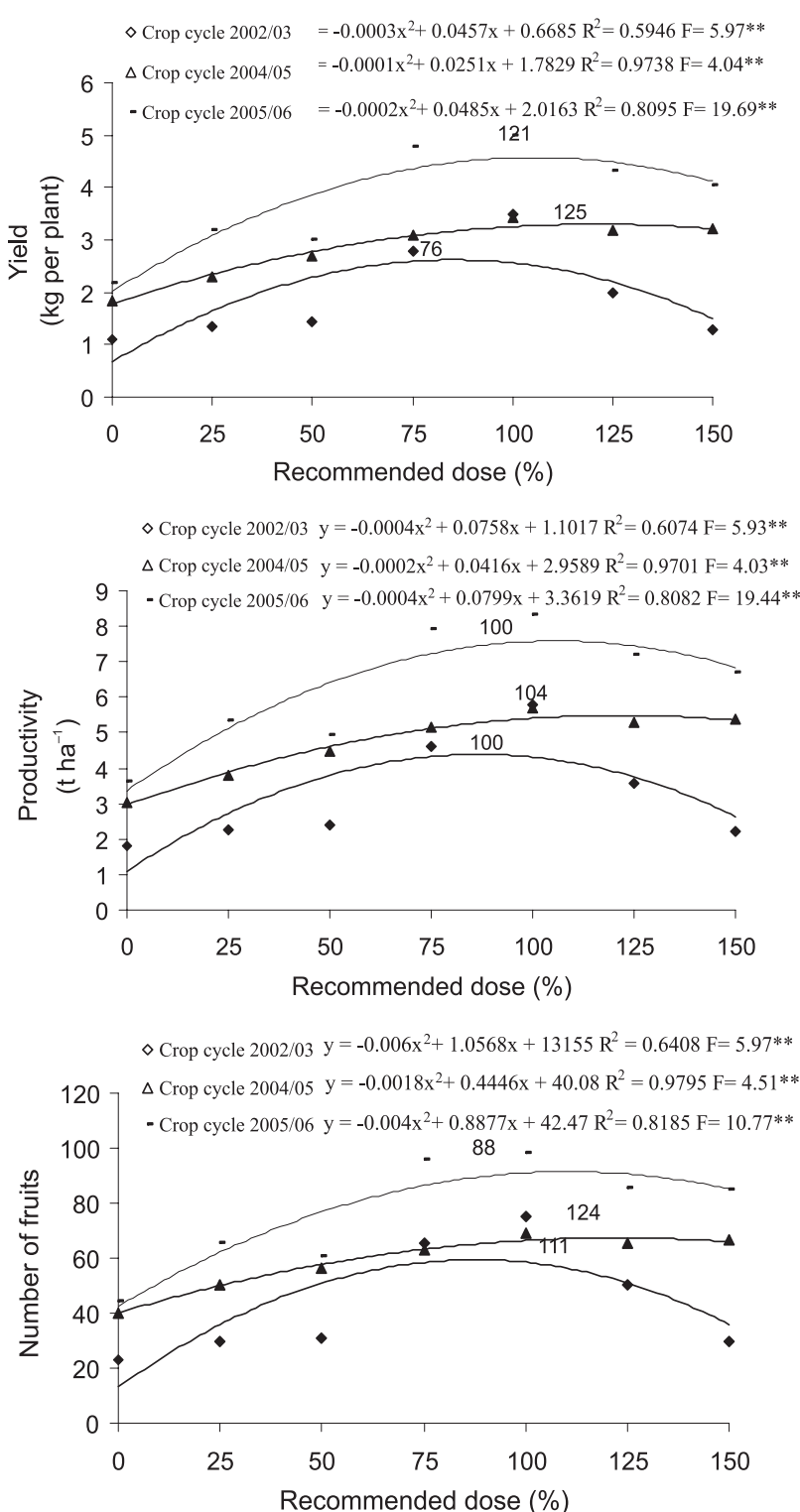

Figure 1 - Yield (kg per plant), productivity $\left(\mathrm{t} \mathrm{ha}^{-1}\right)$ and number of fruits per fig tree fertilized with cattle manure containing different nitrogen levels (\%) (Botucatu, São Paulo State, Brazil - 2007).
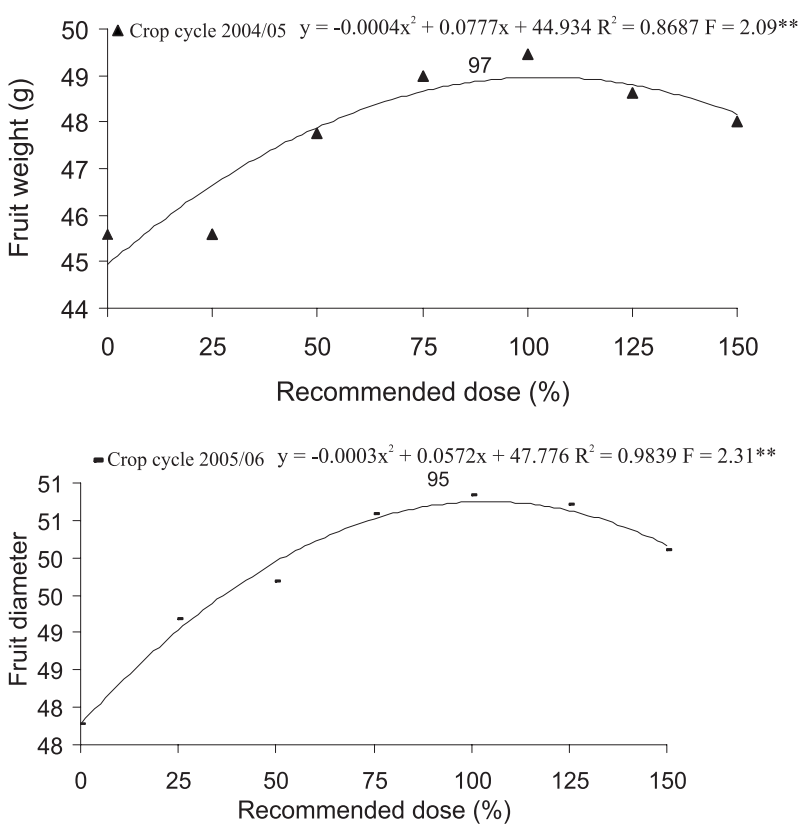

Figure 2 - Weight and diameter of fruits of fig trees fertilized with cattle manure containing different nitrogen levels (\%) (Botucatu, São Paulo State, Brazil - 2007).

regression models to express their increase with increasing cattle manure levels in all cycles, except the2003/04 cycle (Figure 1). The maximum yield, productivity and fruit number were obtained with $76 \%$ to $124 \%$ of the recommended $\mathrm{N}$ level, indicating a mean value of $100 \%$.

The fruits physical evaluation indicated that only their weight (in the 2004/05 cycle) and diameter (2005/06 cycle), presented maximum values. They were $97 \%$ and $95 \%$ of the recommended $\mathrm{N}$ level, according to the fitted the quadratic regression models,, respectively (Figure 2). Although nitrogen content in the cattle manure was low (Table 2), the calculation of levels based on the recommended nitrogen levels was satisfactory, with no readjustment needs. 
Besides N, cattle manure has other minerals that are essential to the development of plants. Kiehl (1985) estimated that cattle manure presents, on average, $17 \mathrm{~g} \mathrm{~kg}^{-1} \mathrm{~N}, 7 \mathrm{~g} \mathrm{~kg}^{-1} \mathrm{P}_{2} \mathrm{O}_{5}, 27 \mathrm{~g} \mathrm{~kg}^{-1} \mathrm{~K}_{2} \mathrm{O}, 12$ $\mathrm{g} \mathrm{kg}^{-1} \mathrm{Ca}, 6.1 \mathrm{~g} \mathrm{~kg}^{-1} \mathrm{Mg}, 31 \mathrm{mg} \mathrm{kg}{ }^{-1} \mathrm{Cu}, 4106 \mathrm{mg}$ $\mathrm{kg}^{-1} \mathrm{Fe}, 510 \mathrm{mg} \mathrm{kg}^{-1} \mathrm{Mn}, 64 \mathrm{mg} \mathrm{kg}^{-1} \mathrm{Zn}$, and $32 / 1$ $\mathrm{C} / \mathrm{N}$ ratio, and supplies small quantities of nutrients to the soil.. Campo Dall'Orto et al. (1996) reported that although presenting low and unbalanced nutrient levels, organic fertilizers carry with them necessary nutrients, which must be considered in fertilization programs. However, those authors emphasized that special attention should be given to the time lapse for the release of nutrients from organic fertilizers to the plants.

Comissão de Fertilidade do Solo de Minas Gerais (1989) and Mielniczuk (1999) reported that nutrient conversion over the years from the organic to the mineral form varies with the nutrient. For nitrogen, approximately $50 \%, 20 \%$ and $30 \%$ are released in the first, second and third year after application, respectively. Campo Dall'Orto et al. (1996) also emphasized that nutrient release from organic fertilizers is slower than from mineral fertilizers, since the former depends on the mineralization of organic material. Such data must be carefully considered in the calculation of levels for organic-only fertilizations since the first harvest can be different from those obtained with conventional mineral fertilization, in which nitrogen is readily released for absorption.

Responses to the application of cattle manure were obtained since the first crop cycle. On the other hand, plant yield during the orchard formation phase was below the mean values obtained by producers who use conventional fertilization. The current results must be considered since the addition of organic material to the soil aims not only to supply nutrients but also to improve the soil physical and biological properties. Although not measured herein, they may have contributed to the yield increases.

The mean last crop cycle (2005/2006) yield obtained was $3.79 \mathrm{~kg}$ of mature fruits per plant, indicating a mean productivity of $6.3 \mathrm{tha}^{-1}$ (Figure 1 and Table 5). However, $100 \% \mathrm{~N}$ level resulted in a mean productivity of $8.3 \mathrm{t} \mathrm{ha}^{-1}(2005 / 2006)$. These values are inferior but comparable to the national mean productivity of figs, which is $8.6 \mathrm{t} \mathrm{ha}^{-1}$ (Ministério da Agricultura, 2006).

Excess of water is one of the disadvantages of the clayey soils: they store a great amount of water when there is excessive rainfall and become hard and compacted when dry; thus manure and/or mulch is recommended to attenuate such a problem (Santos
\& Maia, 1999). Cervellini \& Igue (1994) and Cervellini (1995) evaluated the effect of chemical fertilizers and cattle manure (combined or not) on coffee plant yields and concluded that the addition of manure decreased the mineral fertilizers needs, more significantly for a Oxisol than for an Ultisol. Miysaka \& Okamoto (1992) agreed with them and reported that organic materials change the soil physicochemical characteristics such as density, water retention, texture, structure, porosity and thermal conductivity and increase its cation exchange capacity, as well as base saturation; it also has chelating agents, that may prevent some essential nutrients to become insoluble.

In the high clay content soil of the present study, the added organic material probably improved the development of the fig tree root system, resulting in greater fruit yield. In the Small Meander Valley (Aegean Region of Turkey), where dried fig production is concentrated, Eryuce et al. (1995) selected a lowland orchard cropped with a ten-yearold Calyrmina cultivar, receiving conventional chemical fertilization, and did not observe any effect on fruit length, width and weight. In the Jiangsu Province (Eastern China) where the annual average temperature ranges from $13^{\circ} \mathrm{C}$ to $16^{\circ} \mathrm{C}$, the climate is semi-humid and subtropical, and the annual average rainfall is 800 to $1200 \mathrm{~mm}$ (Jinseng et al. , 1997) studied the effects of supplementary fertilization with nitrogen, phosphorus and potassium on one crop cycle fig trees. They did not report differences among treatments or positive effects on the yield. In the present experiment, the effects on fruit diameter and weight were slighter and the main increases were verified for the number of fruits per plant. The fig tree has continuous growth; thus, increased yield is rather due to the higher growth of the stem than to the increase in fruit size.

Caetano et al. (2006) studied the effects of organic fertilization on fig yield using treatments without (level 0$)$ and with (10 kg per plant) cattle manure, based on the recommendations of Campo Dall'Orto et al. (1996). There were differences among the evaluated levels and the yield was 6,597 g per plant for the treatment without fertilizer and $7517 \mathrm{~g}$ per plant for the $10 \mathrm{~kg}$ manure treatment. Such results indicate a $13.9 \%$ yield increase due to the addition of organic matter, besides the not assessed soil benefits. However, similarly to the present work, the economical viability of this application was not investigated. In the current experiment, there were yield increases for all crop cycles; the four cycles average increase was $45.1 \%$. 


\section{CONCLUSIONS}

Cattle manure fertilization increased the number of fruits per plant, the yield and the productivity of fig trees. The maximum yield, productivity and fruit number were obtained with $76 \%$ to $124 \%$ of the recommended $\mathrm{N}$ level.

\section{ACKNOWLEDGEMENTS}

The authors are grateful to FAPESP (Fundação de Amparo à Pesquisa do Estado de São Paulo) for supporting this study (Process: 01/04398-1).

\section{REFERENCES}

CAETANO, L.C.S.; CARVALHO, A.J.C.; JASMIM, J.M. Preliminary report on yield productivity and mineral composition of the fig trees as a function of boron and cattle manure fertilization in Brazil. Fruits, v.61, p.341-349, 2006.

CAMPO DALL'ORTO, F.A.; CANTARELA, H.; RAIJ, B.van; PIZA JÚNIOR, C.T. Frutas de clima temperado. II. Figo, maçã, marmelo, pêra e pêssego em pomar compacto. In: RAIJ, B. van; CANTARELLA, H.; QUAGGIO, J.A.; FURLANI, A.M.C. (Ed) Recomendações de adubação e calagem para o Estado de São Paulo. 2 ed. Campinas: Instituto Agronômico, 1996. p.139140.

CERVELLINI, G.S.; IGUE, T. Adubação mineral e orgânica do cafeeiro. Bragantia, v. 53, n. 1, p.83-93, 1994.

CERVELLINI, G.S. Modo de aplicação de esterco e de fertilizantes minerais no Cafeeiro. Bragantia, v. 54, n. 1, p.169-176, 1995.

COMISSÃO DE FERTILIDADE DO SOLO DO ESTADO DE MINAS GERAIS. Recomendações para o uso de corretivos e fertilizantes em Minas Gerais. 4. Aproximação. Lavras: CFSEMG, 1989. $176 \mathrm{p}$

CORRÊA, L.S.; BOLIANI, A.C. Cultura da figueira: do plantio à comercialização. Jaboticabal: FUNEP/FAPESP, 2000. 259p.

CUNHA, A.R.; KLOSOWSKI, E.S.; GALVANI, E.; SCOBEDO, J.F.; MARTINS, D. Classificação climática para o município de Botucatu-SP, segundo Koppen. In: SIMPÓSIO EM ENERGIA NA AGriCUlTurA, 1., Botucatu., 1999. Anais. Botucatu: Universidade Estadual Paulista/Faculdade de Ciências Agronômicas, , 1999. p.487-491.

CURI, P.R. Relações entre evaporação média pelo tanque IA-58 e evapotranspiração calculada pelas equações de Thornthwaite e Camargo, para o município de Botucatu. Botucatu: UNESP/ FCMB, 1972. 88p. Tese (Doutorado).

ERYUCE, N.; CALOLOCLU, H.; AUDIN, S.; COKUYSAL, B.; GERASCO POUlOS, D.; OLYMPIOS, C.H.; PASSAM, H. The effects of $\mathrm{K}$ and $\mathrm{Mg}$ fertilization on some quality characteristics and mineral nutrition of fig. Acta Horticulturae, n.379, p.199204, 1995.
FERNANDES, F.M.; BUZETTI, S. Fertilidade do solo e nutrição da figueira. In: CORRÊA, L.S.; BOLIANI, A.C. (Ed.) Cultura da figueira: do plantio à comercialização. Ilha Solteira: FUNEP/ FAPESP, p.69-85, 1999.

GOMES, P. Fruticultura brasileira. São Paulo: Nobel. 1987. $446 \mathrm{p}$.

JINSHENG, Y.; MI-LIN, Z.; YANG, J.S.; MI, L.; ZHOU, Y.H. Preliminary report on application ratis of single fertilizer with nitrogen, phosphorus and potasium in fig tree. Jiangsu Agricultural Sciences, v.4, p.47-49, 1997.

KIEHL, E.J. Fertilizantes orgânicos. São Paulo: Agronômica Ceres, 1985, 492p.

MAlaVOlTA, E.; VITTI, G.C.; OLIVEIRA, S.A. Avaliação do estado nutricional das plantas: princípios e aplicações. 2 ed. Piracicaba: Associação Brasileira de Potassa e do Fósforo, 1987. 319p.

MAIORANO, J.A. Normas de classificação de figo. São Paulo: CEAGESP, 2006. (Documentos, 30).

MIELNICZUK, J. Matéria orgânica e a sustentabilidade de sistemas agrícolas. In: SANTOS, G.A.; CAMARGO, F.A.O. (Ed) Fundamentos da prática da matéria orgânica no solo: ecossistemas tropicais e subtropicais. Porto Alegre: Genessis, 1999. p.1-8.

MINISTÉRIO DA AGRICULTURA, PECUÁRIA E ABASTECIMENTO. Estatísticas. Available at: htpp:// agricultura.gov.br. Acessed 10 Feb. 2006.

MIYSAKA, S.; OKAMOTO, H. Importância da matéria orgânica na agricultura. In: ENCONTRO SOBRE MATÉRIA ORGÂNICA DO SOLO: PROBLEMAS E SOLUÇÕES. Botucatu, 1992. Anais. Botucatu: UNESP/Faculdade de Ciências Agronômicas, 1992. p.1.

PENTEADO, S.R.; FRANCO, J.A.M. Figo. In: Manual técnico das culturas. III. Fruticultura. Campinas: SAA./CATI, p.127140. 1997.

RAIJ, B.van; CANTARELLA, H.; QUAGGIO, J.A.; FURLANI, A.M.C. Recomendações de adubação e calagem para Estado de São Paulo. 2.ed. Campinas: Instituto Agronômico/ Fundação IAC, 1997. 285p. (Boletim Técnico 100).

RAIJ, B.van; QUAGGIO, J.A. Métodos de análise de solo para fins de fertilidade. Campinas: Instituto Agronômico de Campinas, 1983. (Boletim Técnico, 81).

RIGITANO, O. Cultura da figueira. 2 ed. São Paulo: Chácaras e Quintais, 1964. 31p.

SANTOS, J.M.; MAIA, A.S. Nematóides da figueira (Ficus carica L.). In: SIMPÓSIO BRASILEIRO SOBRE A CULTURA DA FIGUEIRA, Ilha Solteira, 1999. Anais. Ilha Solteira: FUNEP, 1999. p.135-149.

UNiTED STATES SOIL CONSERVATION. Soil Taxonomy: A Basic System of Soil Classification for Making and Interpreting Soil Surveys. 1988. 754p.

Received October 09, 2007

Accepted May 15, 2009 